\title{
Feature
}

\section{Approaches to Biology Teaching and Learning: From a Scholarly Approach to Teaching to the Scholarship of Teaching}

\section{Deborah Allen* and Kimberly Tanner ${ }^{\dagger}$}

\author{
*Department of Biological Sciences, University of Delaware, Newark, DE 19716; ${ }^{\dagger}$ San Francisco State University, \\ 1600 Holloway Avenue, San Francisco, CA 94132
}

\section{NEW GOALS AND NEW CHALLENGES}

We live in a time when the seeds of change in science education have borne fruit all around us. The rhetoric of the calls for change issued by national scientific societies and agencies is supported by the reality of compelling examples of change, accomplished by scientists who have rethought the way they teach, the way they think about teaching, and the way they define themselves as science educators (Handelsman et al., 2004; Project Kaleidoscope, 2004).

The seeds have germinated in some potentially rocky soil-including the graduate and postdoctoral training programs that generate future scientists (Luft et al., 2004). For many of us who received our preparation for what we now do as educators before those seeds were sown, however, our graduate and postdoctoral programs may have done justice only to our future roles as research scientists. Our preparation for teaching may have consisted largely of service as a laboratory teaching assistant, or as the deliverer of a curriculum designed by others. When faced with the call to consider the way we teach, we are often on unfamiliar ground-a ground littered with incomprehensible jargon and diverse standards for what constitutes best practice.

Should we go back to the figurative school and, in essence, reinvent ourselves? What is the potential payoff? Do we really have the time to take a scholarly approach to teaching, in addition to the professional demands placed on us in other areas? The three scenarios presented below are offered as illustrations of situations in which scientists who teach are poised at the brink of finding value in the principles and practices that constitute what is an emerging area of scholarship: the scholarship of teaching (Hutchings and Shulman, 1999).

\section{Scenario One}

Cecilia, a new assistant professor, will take on the teaching of a mid-level college course in genetics for the first time next fall. The course has a reputation as being the toughest roadblock to a good biology grade point average that her department's undergraduates face. In thinking about how she will teach the course, Cecilia wonders whether the reputation is deserved-is there something fundamentally different

DOI: $10.1187 /$ cbe.04-11-0052

Address correspondence to: Deborah Allen (deallen@udel.edu). about genetics that makes it so seemingly difficult for novices to learn? Are some curriculum materials and methods more effective than others in helping undergraduates learn to think like a geneticist? Can effective problem-solving skills be transferred from one person's brain to that of another? What have students learned about genetics before they take the course-is their prior knowledge (and perhaps their beliefs) somehow influencing the way they approach the study of genetics in college? If students come into the genetics course thinking they will struggle (and perhaps fail) to do well, does this become the archetypal self-fulfilling prophecy?

\section{Scenario Two}

It is several years later and Cecilia has taught the genetics course from Scenario One five times, with varying degrees of success. Her failures have been painful, and her successes sometimes a little too transitory, but she thinks she has learned a lot about teaching-so much so that she has developed what she thinks are some new curriculum modules and new teaching approaches to support them. She has systematically collected data from hundreds of students that document the nature and extent of their learning as a result of use of the methods and materials. She thinks she should publish her work, but finds the prospect of writing about education to be daunting (her area of research, after all, is in gene expression in the developing brain). And, she reflects, while she has documented to her satisfaction that the strategies she developed are effective at helping her students to meet her course objectives, does that really mean that they would work for anyone else? Why did they work, after all? She is not really sure that she could explain why in a way that would make sense to anyone else, or sound very impressive or scholarly.

\section{Scenario Three}

Cecilia took the bold step of submitting a manuscript describing her approaches to genetics teaching to a peerreviewed science education journal. After some minor and not so minor revisions, her article appears in the spring issue of the journal. Aaron, a genetics instructor at another school, reads the article and immediately gets the sense that Cecilia's approaches would help him get past his current dissatisfaction with the outcomes of his teaching. Along with some colleagues, he intends to write a grant proposal to fund a 
revision of his department's core curriculum, and wants to include within it an adaptation and implementation of Cecilia's novel pedagogies. As he prepares to write the proposal, he reads over the program announcement and is dismayed to find that not only will he have to begin his proposal with a review of the pertinent literature, but will have to address the significance and potential for broad impact of his project, otherwise his proposal will be rejected prior to review.

In these scenarios Cecilia and Aaron are obviously in immediate need of information and advice-the kind they might obtain if they are fortunate to have sympathetic colleagues who are already well down the path to scholarship in science education. But suppose Cecilia and Aaron were intrigued enough by these questions and issues to want to seek their own answers? Is it unrealistic to think that they could learn to take a scholarly approach to teaching, or even become experts in the scholarship of teaching, without retracing all of the complex and time-consuming steps they took to advance beyond apprenticeship in science?

\section{ALTERNATIVES TO RETRACING THE STEPS OF FORMAL EDUCATION}

The good news is that there are examples, and increasingly more of them, of scientists who have become conversant in the whys and wherefores of science education scholarship through a variety of self-educational approaches that sometimes entail capturing a piece of a formal mechanism, or restructuring it to accommodate their current professional circumstances. In essence, they did not discard the general expertise and skills of scholarly practice they acquired through formal undergraduate, graduate, or postdoctoral training programs, but reframed it in a new context. The strategies they have used include the following:

- Co-teaching, or working side-by-side with a more experienced colleague on the same course. If she had started out with this approach before the events of Scenario One, as a new teacher Cecilia would have gained a first-hand look at how an expert conceives of and plans a curriculum, as well as how she or he deals with moments of contingency in teaching - those critical turning points in a classroom at which an on-the-spot decision must be made to respond to a student's inquiry, or about the need to spontaneously revise what in theory had seemed like a good lesson plan. A good co-teaching experience includes regular meetings to deconstruct and reconstruct each classroom experience on the basis of information obtained from informal and formal assessment (Tanner and Allen, 2004), and opportunities to teach and receive spontaneous peer review on what transpired. Most of our colleagues are generous with their time in co-teaching situations (it seems to be part of their makeup), and would welcome your presence as a sounding board for ideas.

- Going back to school. Not as a student enrolled in a degree-granting program, but as a participant in a graduate-level seminar in science education. These seminar-type courses are commonly offered by departments and schools of education with graduate degree programs in or related to science education. While at times the other students in the class might need to display patience about a novice's lack of familiarity with the lingo and methods of science education, a practicing scientist and science educator would have a lot to offer in trade if willing to help ground discussions of educational theory in the realities of the laboratory and classroom by drawing on personal experiences. Many of the issues that Cecilia raises in Scenario One about the teaching of problem-solving to students and how diverse people think and learn would come up (and be revisited) in a seminar of this nature. A seminar course would also help Cecilia in Scenario Two and Aaron in Scenario Three to become more discerning readers of the science education literature. If this type of seminar experience is not available to you, or if the time commitment seems unmanageable, many institutions offer short courses or workshops on current educational issues and practices through their faculty development centers.

- Attending science education meetings. Many scientific societies, the American Society of Cell Biology included, sponsor education sessions at or in conjunction with their annual meetings. Additional opportunities with a broader context in science, mathematics, engineering, and technology education are provided by the SUNY Stony Brook's Reinvention Center (State University of New York at Stony Brook, 2004; recent national meetings have focused on integration of research and undergraduate education), and the National Academies Summer Institutes (National Academy of Sciences, 2004; the first institutes focused on introductory biology course settings). Poster sessions and interactive workshops in particular are a great way to have informal discussions of the approaches taken by experienced scientists-cum-science educators and how they interpreted their findings, as well as providing a sense of what the current "hot" topics are. Cecilia of Scenario Two in particular could benefit by perusing both the poster sessions and symposium, and the workshop presentations, to get a sense of community standards for presentation and publication of her classroom observational data. Attendance at these meetings could also provide opportunities to forge collaborations with colleagues who have ongoing studies in science education - a novice could provide access to another interesting institutional, course, or classroom context for the ongoing study, especially if it entails validation of a survey instrument.

- Forming a science education journal club. This is an approach used by the first author's institution for its "Science Education Lunch Bunch." These monthly, informal discussions of a science education article had a broad constituency, consisting of representatives from all science disciplines, including science education faculty from the School of Education. The latter group, whose idea it was to form the journal club across college boundaries, contributed considerable experience in education research. To the benefit of the novices in the bunch, often the sessions became as much about differences and similarities in norms of accepted practice in science research versus science education research as it did about the more immediate topics of the article. Participants' knowledge base and awareness increased by leaps and bounds, the informal setting encouraged them to feel comfortable about the occasional (or even frequent) admission of ignorance, and the monthly format respected their time constraints. Several ongoing research collaborations were formed across what can sometimes be a disciplinary divide in educational perspectives. 
- Reading the science education literature. Starting first with the most accessible types of articles that appear in journals targeted mostly to teaching practitioners/educators, whose formal training has been in a science discipline rather than in science education.

- A need to delve into the science education literature is a common thread that underlies the other four approaches. All of the questions and issues raised in the scenarios at the start of this essay, although perhaps not framed specifically in the same contexts in which Cecilia and Aaron have encountered them, have been investigated and written about extensively in science education journals by scientists and science educators who practice the scholarship of teaching. The remainder of this essay will thus be devoted to identifying key sources of information for addressing the myriad of whys and wherefores and how-to-do it questions and issues that arise in the normal course of teaching.

\section{AN OVERVIEW OF SELECTED SCIENCE EDUCA- TION JOURNALS}

For the purposes of this overview, we have classified journals into two major broad categories that seem to fall with reasonable clarity at either end of a spectrum, with practice at one end and theory and research at the other. In using the term "practice-oriented," we refer to journals that, for the most part, contain descriptive articles and reports on the organization and operation of programs and courses, and on novel curriculum materials and teaching and learning activities. In many cases, but not all, at least some information is provided about the effectiveness of these practices, procedures, programs, and materials. We use the term "theory and research-oriented" to describe journals that contain reports of empirical and analytical research on questions related to the psychology of learning. These journals also contain articles about practices and controversies that are interpretative and philosophical in nature. The following, more extensive descriptions, may serve to clarify the basis for making these distinctions.

\section{Practice-Oriented Journals}

The stated missions of these journals, typically sponsored by a national scientific society, clearly are the improvement of teaching and learning in their discipline. As such, the featured articles are typically aimed at offering innovative teaching approaches and pedagogically sound teaching materials in a way that helps a science instructor envision how to use them in the classroom. The use of educational jargon typically is kept to a minimum so that the contents are readily accessible to a readership that encompasses the entire $\mathrm{K}-16+$ community of science educators. Most of the journals in this category (examples appear in Table 1) are sponsored by a national science society that may be either broad in scope (such as the sponsors of The American Biology Teacher, BioScene, and the Journal of College Science Teaching), or more focused on a particular subdiscipline within the life sciences (for example, the sponsors of Advances in Physiology Education, Biochemistry and Molecular Biology Education, and Microbiology Education). Cell Biology Education is somewhere in between these two dimensions of scope-its focus is cell biology, but it reaches out to publish articles of interest in all areas of the life sciences. The inception and growth of many of the journals whose scope is largely defined by a subdisciplinary area of the life sciences often parallels that of the emergence of a strong education section within the sponsoring national society.

A subtext of all of the practice-oriented journals is that they build on what is familiar to the reader-the incremental observations from day-to-day classroom practice (known collectively as teacher lore)-and then seek to elevate this practice as an area of scholarship by subjecting it to inspection and analysis by peers. From the onset (depending on year of origin) these journals generally have as a criterion for acceptance the provision of evidence of outcomes. In the early stages of their evolution, however, in some instances they were ambiguous about their standards for what constituted evidence, perhaps because the scientist education scholar was then a rare breed. Examples can be found of accepted articles that provide solely survey-based, student self-reported data about qualitative aspects of a course experience, particularly in the older literature. Judging by their instructions to authors and the contents of current issues, most of these journals now have upped the ante, as it were, on their standard of evidence (e.g., see the "Instructions for Authors" in Cell Biology Education), and in some cases explicitly require a "pedagogical justification arising from learning theory or published research findings" (quoted from descriptions of "Types of Articles" in a 2004 issue of Advances in Physiology). Some of the journals, however, acknowledge the value of sharing truly novel and creative ideas that are narrower in scope and extent of documentation than is typical for a full manuscript, but may place these contributions in a special section of the journal.

Typically, each journal will have special features in addition to articles-such as reports on society meetings; reviews of textbooks and other books about the history, nature, and politics of science; reviews of curriculum resources (including technology resources); tried-and-true laboratory activities; and viewpoints on current issues and controversies of broad, national interest. (Cell Biology Education adds a special touch to the latter by presenting these controversies in point-counterpoint fashion in a collection of essays by separate authors.) In addition, they often have a special feature or area of interest that, in addition to a subdisciplinary or multidisciplinary focus, may distinguish the journal from the others we have placed in this practice-oriented category.

\section{Theory and Research-Oriented Journals}

Given what has previously been said about practice-oriented journals and their requirement for evidence of outcomes, you may wonder why we have chosen to create this additional category of science education journals and label it (but not the other) as research-oriented. We see a distinction, although we admit that it is becoming increasingly more blurred. Using two premier journals to represent this category, The Journal of Research on Science Teaching (NARST, 2004) and Science Education, we see a distinction in the "community" practices and standards for what constitutes research. Although this is a generalization, many of the authors tend to be affiliated with schools and departments of education, rather than basic science departments. Perhaps as a result, the published articles encompass topics such as cultural and comparative studies (including greater inclusion 
Table 1. Science education journals, primarily practice-oriented, including their society sponsorship, specialty areas (if present), and accessibility to sponsor society nonmembers

\begin{tabular}{|c|c|c|c|c|}
\hline Journal name & Sponsoring society & $\begin{array}{l}\text { Issues } \\
\text { per year }\end{array}$ & $\begin{array}{l}\text { Publication } \\
\text { format and access }\end{array}$ & Sample distinguishing feature ${ }^{a}$ \\
\hline \multicolumn{5}{|c|}{ Practice-oriented journals } \\
\hline $\begin{array}{l}\text { Advances in Physiology } \\
\text { Education }\end{array}$ & $\begin{array}{l}\text { American Physiological } \\
\text { Society }\end{array}$ & 4 & $\begin{array}{l}\text { Print and electronic; } \\
\text { free access to } \\
\text { electronic version }\end{array}$ & $\begin{array}{l}\text { New strategies for teaching; } \\
\text { "Staying Current" reviews } \\
\text { of research advances to assist } \\
\text { with translation to students; } \\
\text { reviews of education research } \\
\text { and psychology }\end{array}$ \\
\hline $\begin{array}{l}\text { Biochemistry and Molecular } \\
\text { Biology Education }\end{array}$ & $\begin{array}{l}\text { American Society } \\
\text { for Biochemistry } \\
\text { and Molecular Biology }\end{array}$ & 6 & $\begin{array}{l}\text { Print and electronic; } \\
\text { currently, access } \\
\text { by subscription }\end{array}$ & $\begin{array}{l}\text { Featured columns } \\
\text { on problem-based learning } \\
\text { and biotechnology education }\end{array}$ \\
\hline The Biology Teacher & $\begin{array}{l}\text { National Association } \\
\text { of Biology Teachers }\end{array}$ & 9 & $\begin{array}{l}\text { Print and electronic; } \\
\text { access by subscription } \\
\text { or membership }\end{array}$ & $\begin{array}{l}\text { Focused on K-12 setting; } \\
\text { teaching of evolution } \\
\text { controversy often highlighted; } \\
\text { requirement that submitted } \\
\text { manuscripts align with the } \\
\text { National Science Education } \\
\text { Standards and focus } \\
\text { on inquiry-based learning }\end{array}$ \\
\hline BioScene & $\begin{array}{l}\text { Association of College } \\
\text { and University } \\
\text { Biology Educators }\end{array}$ & 1 & $\begin{array}{l}\text { Print and electronic; } \\
\text { free access to } \\
\text { electronic version } \\
\text { (6 month delay) }\end{array}$ & $\begin{array}{l}\text { Focused on integrating history } \\
\text { and philosophy of science } \\
\text { perspectives into courses, } \\
\text { and on reporting society } \\
\text { issues and events }\end{array}$ \\
\hline Cell Biology Education & $\begin{array}{l}\text { American Society } \\
\text { for Cell Biology }\end{array}$ & 4 & $\begin{array}{l}\text { Electronic and one } \\
\text { print issue per year; } \\
\text { free access }\end{array}$ & $\begin{array}{l}\text { Research and descriptive articles } \\
\text { on life science education; } \\
\text { reviews of resources } \\
\text { and debate on current issues }\end{array}$ \\
\hline $\begin{array}{l}\text { Journal of College Science } \\
\text { Teaching }\end{array}$ & $\begin{array}{l}\text { National Science Teachers } \\
\text { Association }\end{array}$ & 6 & $\begin{array}{l}\text { Print and electronic; } \\
\text { access by subscription } \\
\text { or membership }\end{array}$ & $\begin{array}{l}\text { Featured column and periodic } \\
\text { issues devoted to teaching } \\
\text { with case studies }\end{array}$ \\
\hline
\end{tabular}

${ }^{a}$ An example of an article type, featured column, or topical focus that, in addition to a subdisciplinary or multidisciplinary focus, is a different or even distinguishing feature of the journal.

of studies performed in other countries), cognitive psychology, and the influence of beliefs and identities on teaching and learning in a given classroom culture. While much of the published work is based on experimental investigations, articles by authors who have used qualitative, ethnographic, historical, philosophical, or case study research approaches are also well represented. In addition, although both journals include in their self-description the intent to inform the practice of teaching, they give equal emphasis to their contribution to advancing educational theory.

It is perhaps this use of a broad range of topical areas, methodologies, and the associated terminology that can make this category of journal seem fairly inaccessible to the typical scientist who is interested in or compelled by circumstances to delve into the science education literature. Studies that are seemingly without comparison groups, or that include interviews treated as a source of data for systematic analysis rather than as collection of anecdotes, might leave a novice reader whose formal education has been primarily in the sciences, with little sense of how to judge the validity of the work that is presented. She or he would have little familiarity with the intellectual tradition that has refined these methodologies and their applications to different research questions. A quick glance through a current issue can thus be a difficult experience for such a reader, and a good reminder of how exclusionary the science 
literature can seem to those accessing it for the first time because of its requirements for a reader's understanding of complex methodologies and use of highly technical jargon.

Why, then, would a scientist-science educator want to struggle with learning the norms of this other cultural tradition in science education? To consider what a motivation might be, we can return to the scenarios about Cecilia. It is in the literature we have placed in this theory and research-oriented category that she might find answers to her earliest, cognitive science and learning-theory related questions about the students in her upcoming genetics course (Scenario One). She could also enrich her research into what transpires in her classroom by an encounter with qualitative and ethnographic approaches that are traditional in this branch of science education literature.

And fortunately, there is a more recent trend toward inclusion of crossover literature in journals we have placed in these major categories. In perusing recent issues of Science Education and The Journal of College Science Teaching, for example, Cecilia could find articles relevant to her questions and concerns about genetics teaching and learning that are written by authors who seem conscious of the need to be accessible to scientists interested in science education, as well as to professional science education specialists. In many cases, these articles have been written by scientists who are self-educated in science education. In an example that connects again with Cecilia's questions from Scenario One, Baker and Lawson (2001) report in Science Education on their use of the familiar experimental design of pretest and posttest comparisons among various "treatment" groups to explore effective ways to help boost students' success in college-level genetics. In particular, they examined the effect of complex instructional analogies (designed to link theoretical concepts in genetics with observable or familiar phenomena) on student achievement on a test of scientific (hypothetico-deductive) reasoning and on weekly quizzes that assessed genetics knowledge. In another example, Thompson and Stewart (2002) examined the strategies used by geneticists (transmission, molecular, and population) for solving problems of four types. Their broader goal in conducting this study again connects directly with one of Cecilia's concerns, and could inform the instructional decisions she faced-that is, they offer their analysis of the geneticists' insights and problem-solving frameworks to guide instructional choices and practices, including inquirybased problem-solving in areas other than genetics.

\section{FROM A SCHOLARLY APPROACH TO TEACH- ING TO THE SCHOLARSHIP OF TEACHING}

What are my students really learning? How do the materials and methods that I use in my teaching affect that learning, and how might it be done more effectively? These essential questions, at the heart of the set of practices known as classroom assessment, were the central premise for this Teaching and Learning Feature of Cell Biology Education in the summer issue. We introduced fundamental considerations in classroom assessment, and provided an annotated list of resources aimed at helping educators to put these ideas into practice in their classrooms (Tanner and Allen, 2004).

By placing the discussion of assessment in the context of methodologies for framing fundamental questions about student learning, as well as in the context of the systematic inquiry and investigation that attempts to answer those questions, we were also making a case for an approach to teaching that is scholarly in nature (Boyer, 1990). In this issue's column, we have continued with a similar theme, but expanded our consideration of scholarly approaches to teaching and learning beyond the immediacy of evidencegathering in the course of instruction. That is, we considered approaches and resources that allow us to develop our knowledge base on a broader range of issues in science education, and provided a short, annotated list of peerreviewed journals that aim to inform both the theory and practice of teaching and learning. These science education journals publish the findings of scientists who, like Cecilia in Scenario Three, have taken their scholarly approach to teaching several steps beyond student-reported classroom assessment, based on current ideas about best practice, to an approach that can be defined as the scholarship of teaching. By making this distinction (as proposed by Hutchings and Shulman, 1999), we mean that the scientists who have published in these journals have not only taken a systematic and informed approach to gathering evidence, but have also taken their work outside of the classroom and made it public, thus exposing it to critique and evaluation by peers. They have documented their work in a form that allows a broader community of scholars to build on it and advance practice beyond it. Hutchings and Shulman (1999) further describe the scholarship of teaching as a practice that draws synthetically from the other scholarships. It begins in scholarly teaching itself. It is a special case of the scholarship of application and engagement, and frequently entails the discovery of new findings and principles. At its best, it creates new meanings through integrating across other inquiries, negotiating understanding between theory and practice. Where discovery, engagement, and application intersect, there you will find teaching among the scholarships.

\section{REFERENCES}

Baker, W.P., and Lawson, A.E. (2001). Complex instructional analogies and theoretical concept acquisition in college genetics. Sci. Educ. 85(6), 665-683.

Boyer, E.L. (1990). Scholarship reconsidered: priorities of the professorate. The Carnegie Foundation for the Advancement of Teaching. Princeton, NJ: Princeton University Press.

Handelsman, J., Ebert-May, D., Beichner, R., Bruns, P., Chang, A., DeHaan, R., Gentile, J., Lauffer, S., Stewart, J., Tilghman, S.M., and Wood, W.B. (2004). Scientific teaching. Science 304(5670), 521-522.

Hutchings, P., and Shulman, L.S. (1999). The scholarship of teaching: new elaborations, new developments. Change 31(5), 10-15.

Luft, J.A., Kurdziel, J.P., Roehrig, G.H., and Turner, J. (2004). Growing a garden without water: graduate teaching assistants in introductory laboratories at a doctoral/research university. J. Res. Sci. Teaching 41(3), 211-233.

National Academy of Sciences. (2004). The National Academies Summer Institutes on Undergraduate Education in Biology. http:// www.academiessummerinstitute.org/ (accessed 30 November 2004).

National Association for Research in Science Teaching (NARST). (2004). Web site and JRST information. http://www.educ.sfu.ca/ narstsite/publications/jrst.html (accessed 17 November 2004). 
Project Kaleidoscope (PKAL). (2004). What works-what is learned, Biology Portfolio. http://www.pkal.org/template2.cfm?c_id=585 (accessed 17 November 2004).

Tanner, K., and Allen, D. (2004). From assays to assessments: on collecting evidence in science teaching. Cell Biol. Educ. 3(3), 69-74.
State University of New York at Stony Brook. (2004). The Reinvention Center at Stony Brook. http://www.sunysb.edu/ Reinventioncenter/ (accessed November 30, 2004).

Thomson, N., and Stewart, J. (2002). Genetics inquiry: strategies and knowledge geneticists use in solving transmission genetics problems. Sci. Educ. 67(2), 161-180.

\section{Appendix A \\ WEB SITES (IF AVAILABLE) FOR JOURNALS LISTED IN TABLE 1}

\section{Journals with Free-Access Contents Online}

American Physiological Society. (2004). Advances in Physiology Education. http://advan.physiology.org/ (accessed 17 November 2004).

American Society for Cell Biology. (2004). Cell Biology Education. http://cellbioed.org/ (accessed 30 November 2004).

Association of College and University Biology Educators. (2004). BioScene: Journal of College Biology Teaching. http:// papa.indstate.edu/amcbt/publications/index.html (accessed 15 November 2004).

Faculty for Undergraduate Neuroscience. (2004). Journal of Undergraduate Neuroscience Education. http://www.funjournal. org (accessed 3 February 2005).

\section{Journals with Online Table of Contents Only (Journal Access by Subscription)}

American Society of Biochemistry and Molecular Biology. (2004). Biochemistry and Molecular Biology Education. http:// www.bambed.org/ (accessed 17 November 2004).

National Association of Biology Teachers (2004). American Biology Teacher. http://www.nabt.org/sup/publications/ default.asp (accessed 17 November 2004).

National Science Teachers Association. (2004). Journal of College Science Teaching. http://www.nsta.org/college\#journal (accessed 17 November 2004).

American Society for Microbiology. (2004). Microbiology Education. http://www.asm.org/Education/index.asp?bid=24971 (accessed 18 November 2004). 